\title{
Mechanization and Automation by the Manufacturing of Removable Modular Buildings
}

\author{
Frans van Gassel \\ Eindhoven University of Technology, Faculty of Building and Architecture, \\ P.O. BOX 513, NL 5600 MB Eindhoven, The Netherlands.
}

\begin{abstract}
During the last ten years Removable Modular Building Systems in the Netherlands have made remarkable progress by using mechanization and automation.

These are not the only techniques, as logistic techniques, design according to a modular system and standardization of joints, are also used.

An interesting question is what designers of permanent buildings and building processes can learn from these techniques.

To get insight into the manufacturing of Removable Modular Buildings this system has been described. The problems related to the production of permanent buildings are mentioned too.

The answer to the question: "What can we learn about mechanization and automation by the production of Removable Modular Buildings for the construction of permanent buildings?", is:

- Reducing the construction processes on the site to simple transport and assembly processes allows mechanization and robotization to become less complex.

- It is possibly to develop components with standard joints (design by construction).

- All information about the product and its production process can be stored in one data-base.
\end{abstract}

\section{INTRODUCTION}

The Advisory Committee for Technological Policy in the Building Industry (Adviesraad Technologiebeleid Bouwnijverheid ARTB) predicts two strategies for the coming years in its publication Building Outlook for 2010 (Bouwvisie 2010):

- Optional standardization: to standardize industrially manufactured, not project-depend vent, components to make individual buildings.

- Flexible production organization: to manufacture standardized components with a series of one piece [1]. 
The manufacturing of Removable Modular Buildings in the Netherlands already involved these strategies. It is interesting to see what the mechanization and automation of the production of these buildings means for the production of permanent buildings on the site.

This paper tries to give an answer to the question:

"What can we learn about mechanization and automation by the production and construction of Removable Modular Buildings for the construction of permanent buildings?".

To gain some insight into the production and construction of buildings, we first have to look at the basic processes. The building process generally consists of three kinds of processes:

- The production of semi-finished products in the factory.

- The transportation of these products to the construction site and to the process place.

- The construction of the building.

The relations between the processes are given in figure 1 .

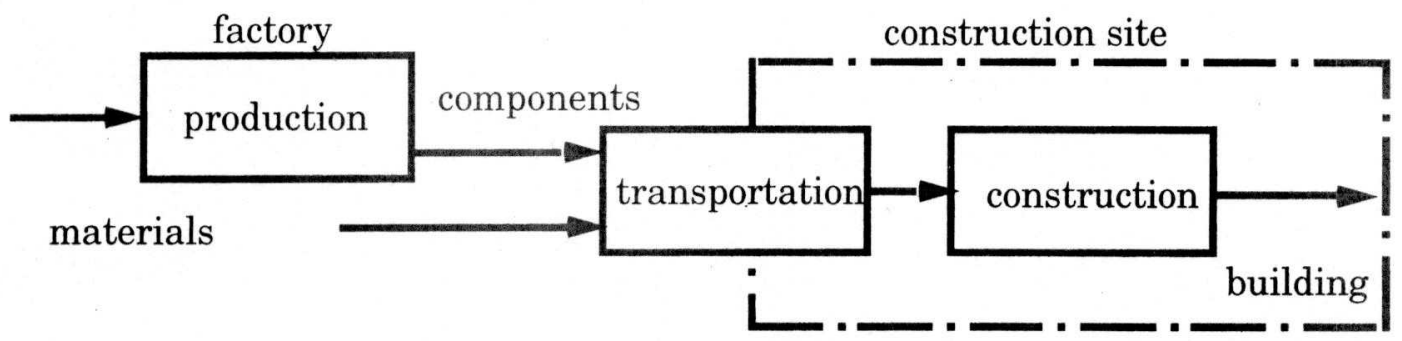

Figure 1. Scheme of the basic building processes.

To carry out the processes of production, transportation and construction, workers and equipment are needed. Mechanization is defined as the shifting of tasks from worker to equipment. Robotization is a special type of mechanization. Here, all tasks are shifted from the worker to the equipment [2]. Automation is also a special type of mechanization; only the steering tasks are shifted from the worker to the equipment. Automation equipment includes computers, software and peripheral devices.

\section{THE MARKET}

Removable Modular Buildings are used for non-residential purposes such as offices, schools and sometimes also for hotels and temporary housing. See figure 2 for a RMB building designed recently.

The client chooses for RMB when he wants:

- A rapid design and price of a building he specifies.

- To accept a restricted possibilities of the building.

- The same performance as a permanent building.

- Speedy delivery.

- A specified time for the use of the building in one or more places.

- Options for a larger or smaller building.

- A special financing method: buy, hire, lease and buy back. 
After a specified period the building has to go back to the manufacturer. He can sell the building again in another configuration or if the buildings are used up he can opt to disassemble them.

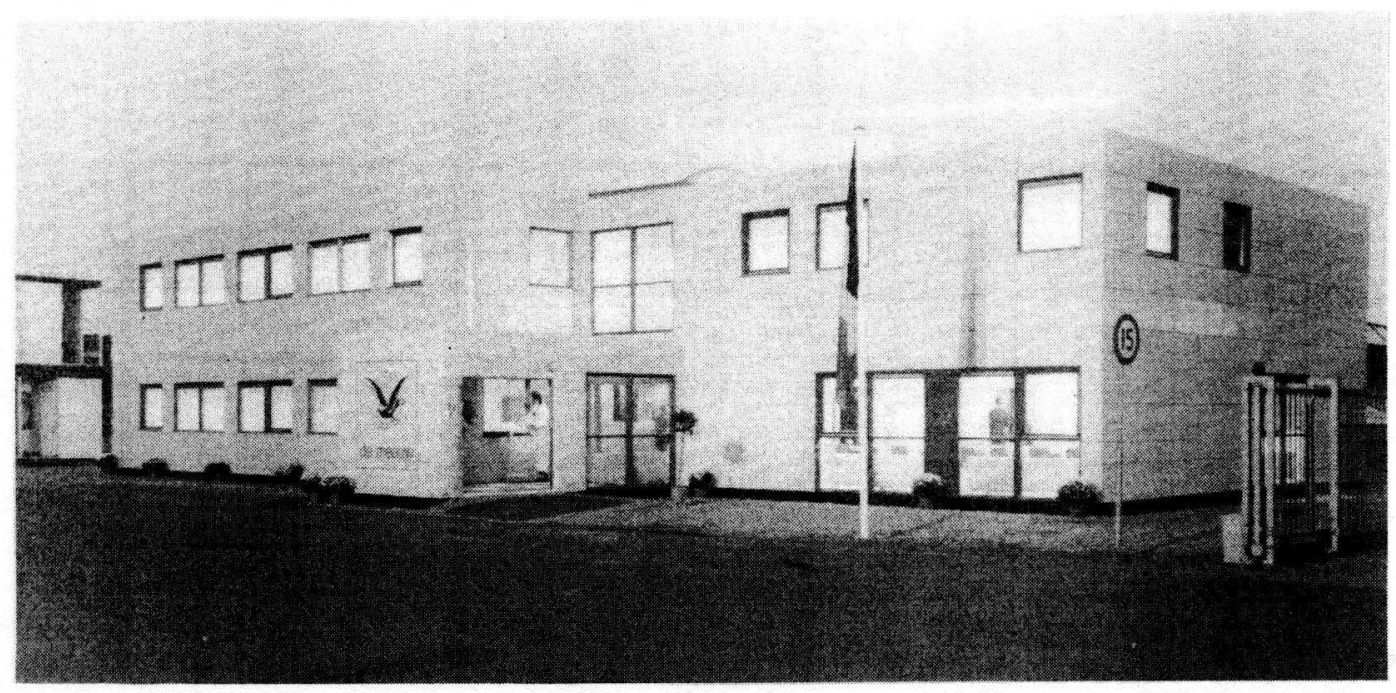

Figure 2. Dutch Removable Modular Building functioning as an office.

\section{THE CONSTRUCTION}

A Removable Modular Building consists of ready-for-use transportable spaces made in the factory. On the construction site the spaces are assembled to a building.

The spaces made in the factory consist of the following parts:

- Rectangular parallelpiped steel frame, dimensions about 6 metres long, 3 metres wide and 3,2 metres high.

- Floor: steel beams, insulation and wooden sheet material.

- Roof and ceiling: timber framed panels with wooden sheet material, insulation, bituminous roofing.

- Facade: timber framed panels, insulation, steel sheet material.

- Interior panels: steel framed panels with wooden sheet material, insulation.

- Installations (electrics, heating, ventilation, communication, water supply and sewer).

See also figure 3 for the construction of the frame.

\section{THE MANUFACTURING}

The manufacturing process of a RMB can be divided into the following processes:

- Buying materials and semi-manufactured components.

- Producing semi-manufactured components.

- Assembling spaces.

- Transporting spaces.

- Assembling the building. 


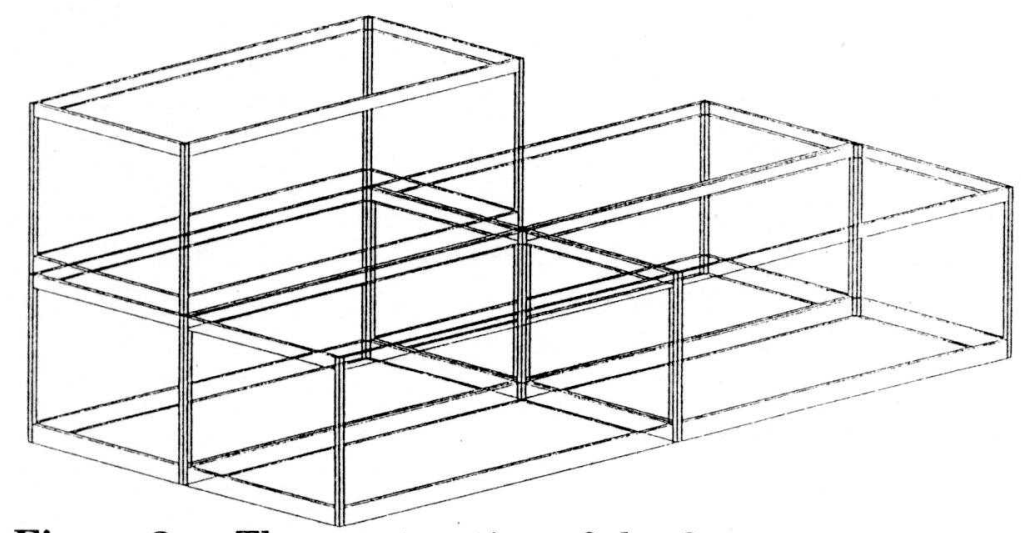

Figure 3. The construction of the frame.

The production of the semi-manufactured components takes place in production cells. The numbers are very high and the production is mechanized for some components:

- The floor and roof steel frames are manufactured in welding templets, no measuring is necessary and the weld is made by the welder. Because of the great number of frames the welding is easy to robotize.

- The profiling of the steel sheets of the facade is fully robotized by a specially designed machine.

- The production of the timber framed panels is also robotized.

As a result of all these semi-manufactured components the dimensions are flexible and the joints are standardized

The assembling of the components to a space takes place on an assembly line. See figure 4. The following components are stocked near the line: floor frames, columns, roof frames, exterior and interior panels and material for the installations.

The assembly line is about 60 metres long, produces four spaces in eight hours and the labour time is about 20 - 40 hours for one space.

The equipment that the assembly workers use are overhead cranes with special hoist provisions, trolleys and special power-driven hand tools. No measuring is needed. The assembling of the spaces can be further mechanized and robotized, as already happens on the assembly line in the car industry.

The transport of the spaces from the assembly line to the construction site is done with special trucks. A transport distance of about $250 \mathrm{~km}$ at a maximum is economically viable.

On the construction site the spaces are assembled by a mobile crane and special hoist provisions to a building. The joints between the steel frames are very simple, being a further development of the LEGO system. The final position of the spaces is the result of a forced movement, so that the positioning of the crane does not need to be very accurate.

On the site it was possible to assemble four spaces in one hour. The work had to be done by the crane driver and two workers. 


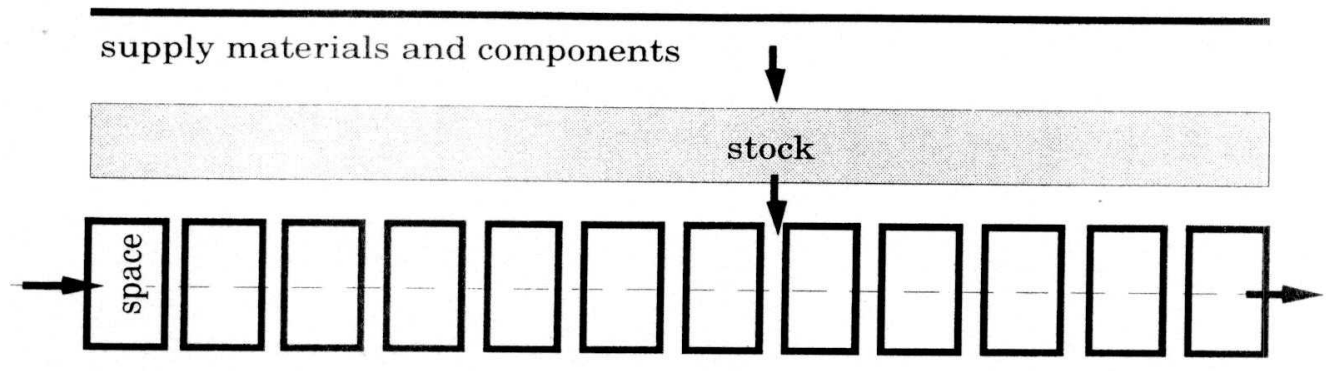

assembling:

floor - columns - roof - facades - interior partitions - installations

Figure 4. The assembly line of the spaces.

After placing the spaces the line joints between floors, walls, ceiling and roof had to made. Only a maximum on material and equipment was necessary. The time needed for this was about 10 man hours for a space of $18 \mathrm{~m}^{2}$.

The materials and the standard semi-manufactured components are made in stock and the assembled spaces are made to order. The order disconnection point is the beginning of the assembly line. This means that the production time between the start of the assembly line and the delivery of the building must be minimal.

\section{AUTOMATION OF THE LOGISTIC SYSTEM}

The lay out of the building is drawn by a computer. The architect or the designer of the manufacturer of RMB only draws with virtual product components. These are, for instance, the space frame, an exterior window panel, an interior door panel or a water closet. The drawing (and the related data-base) can be used for several purposes:

- The client can be shown what the building will be like.

- The total price can be derived, as each virtual product component has a price.

- The entire production schedule can be planned.

- The buying of materials and parts.

In figure five a materials tree of a space is shown. A special part of this tree is the virtual product component.

\section{MODULAR TECHNIQUES}

The development of the product and process happens at the same time. The Removable Modular Building is developed as a system with minimal components and maximum possibilities. Modular techniques are used by the structure, outer and inner partitions and installations. The sophisticated design of the component is very important, but more important is the design of the joint between the components. By RMB the joints are standardized and the components can be manufactured in a wide but specific range of dimensions and materials. 
So the manufacturing of components by RMB is complex, while the assembly is simple with the use of special equipment or tools. Figure 6 makes a comparison with the traditional production process.

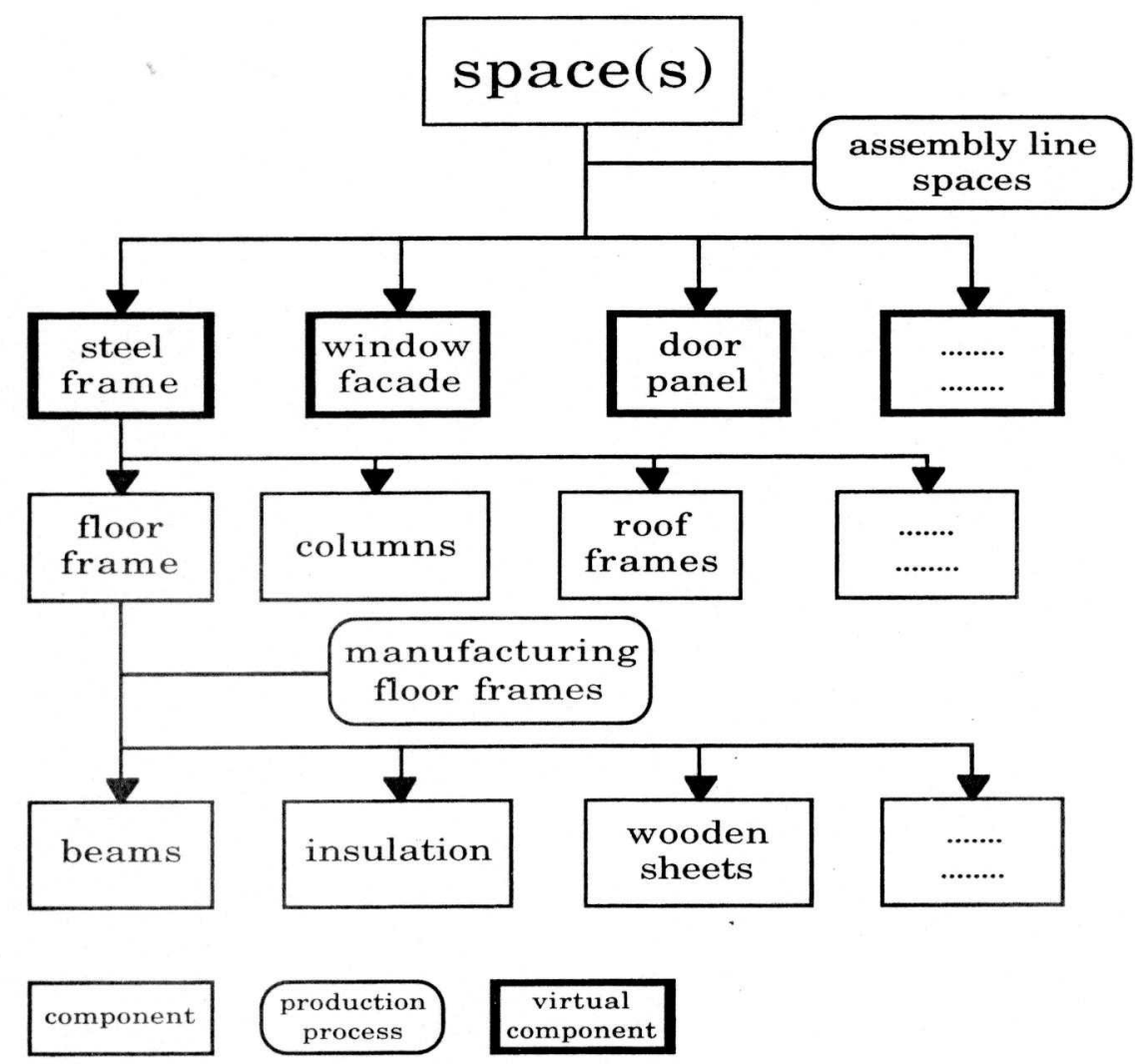

Figure 5. Materials tree of a space.

In RMB the joints should allow for disassembly without damaging the components. This is not possible with traditional components. For the addition of an intermediary component in the joint, rapid disassembly has been made possible.

Special components are added to the space or building at the latest possible point in the production chain. The client asks for special fire-, for instance, resistant walls, no special walls are made. A special wall component is assembled on the assembly line up on the standard wall.

\begin{tabular}{||l|l|l||}
\hline & Traditional & RMB \\
\hline \hline Component & simple & complex \\
\hline Joint & complex & simple \\
\hline Equipment & complex & special \\
\hline
\end{tabular}

Figure 6. Comparison traditional and RMB production. 


\section{PERMANENT BUILDINGS}

Considering the production of permanent buildings, and especially the residential houses built in the Netherlands, the following developments are
remarkle:

Prefabricati

Prefabrication of flat parts: foundations, floors, roofs, exterior and interior
wall panels, windows and doors.

- Prefabrication of spaces: stairs.

- Prefabrication of larges: stairs, dormer windows, kitchens.

- Little prefabrication by components (project-dependent).

- Mechanization on the assembling of installations. components and workers, pumping and finishingly cranes only, lifts for and other liquid products.

- Using all kinds of hand tools: screwing, sawing and grinding.

The production of traditional buildings and removable modular buildings is coming closer and closer together. An illustration is a photo of permanent
houses in production. See the photo in figure 8 .

In the Netherlands the managers of material departments of the big residention contractors find the development of large equipment for (non-) of tools. The technologies used for mechen in comparison with the development of large equipment exist. Technologies for thobotization and automation consideration: electronic fieldbook, comies for the crane driver are under system of the contractor and positioning of thication by a modem with the CAD

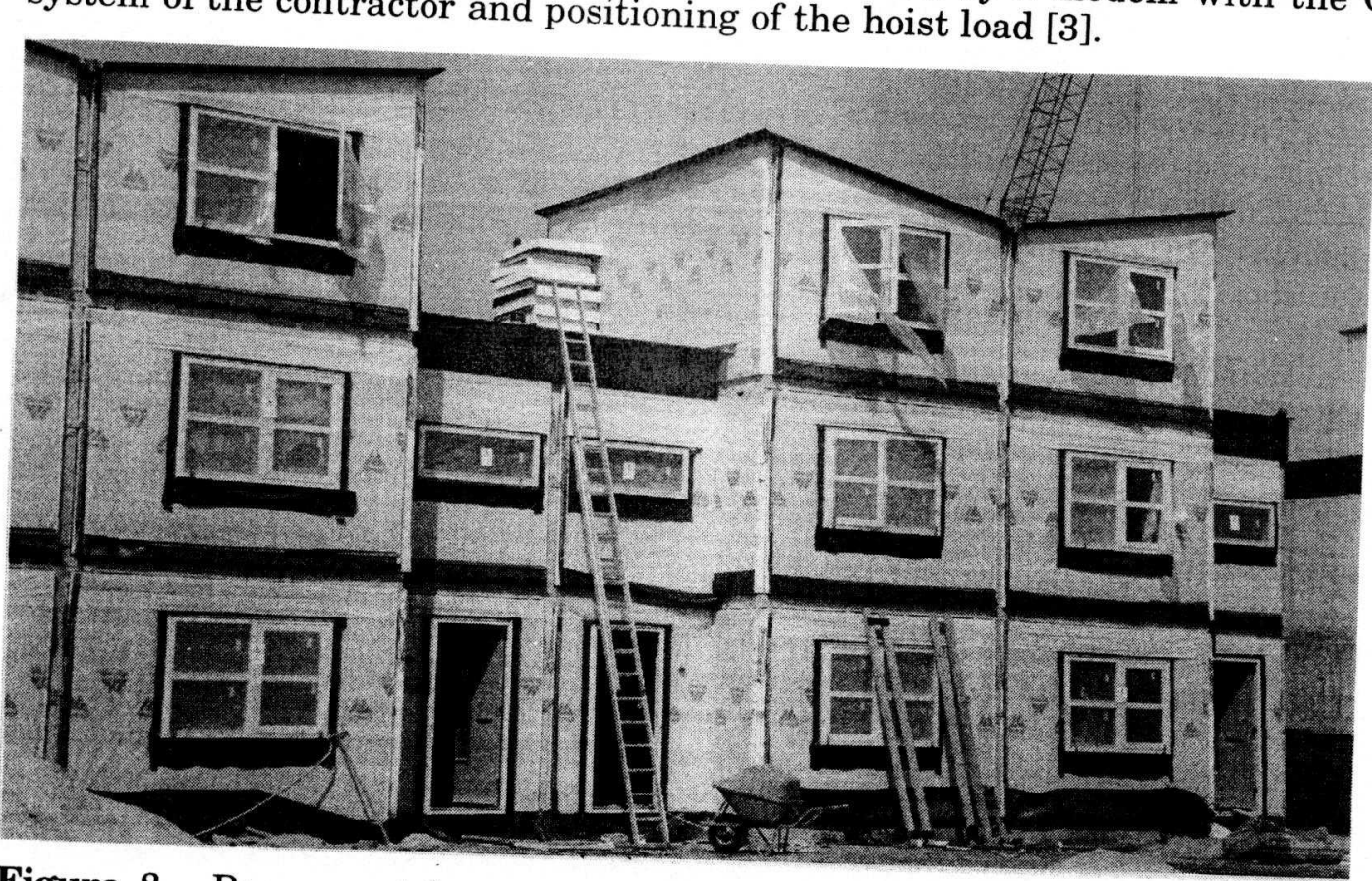

Figure 8. Permanent houses in construction. 


\section{CONCLUSION}

In figure 9 the problems of the construction of permanent buildings and the contrasts with RMB are displayed.

\begin{tabular}{|c|c|c|}
\hline & Permanent buildings & RMB \\
\hline $\begin{array}{l}\text { Mechanization } \\
\text { Robotization }\end{array}$ & $\begin{array}{l}\text { - traditional construction } \\
\text { methods are complex } \\
\text { - prefab components are } \\
\text { project dependent } \\
\text { - no standardization of the } \\
\text { joints }\end{array}$ & $\begin{array}{l}\text { - a high grade of mecha- } \\
\text { nization is not necessary on } \\
\text { the site } \\
\text { - many possibilities for } \\
\text { mechanization on the } \\
\text { assembly line and in } \\
\text { production cells because } \\
\text { the components are project } \\
\text { independent } \\
\text { - flexible production in } \\
\text { dimensions and series } \\
\text { - minimal instruction for the } \\
\text { workers to begin assembly }\end{array}$ \\
\hline Automation & $\begin{array}{l}\text { - no integration between } \\
\text { product and process } \\
\text { design. }\end{array}$ & $\begin{array}{l}\text { simultaneous development } \\
\text { of the modular components } \\
\text { and their production and } \\
\text { assembly process. }\end{array}$ \\
\hline
\end{tabular}

Figure 9. Problems permanent buildings and the changes of RMB.

The answer to the question: "What can we learn about mechanization and automation by the production of Removable Modular Buildings for the construction of permanent buildings?", is:

- Reducing the construction processes on the site to simple transport and assembly processes allows mechanization and robotization to become less complex.

- It is possibly to develop components with standard joints (design by construction).

- All information about the product and its production process can be stored in one data-base.

\section{REFERENCES}

[1] ARTB Bouwvisie 2010, A study commissioned by the Dutch government in order to outline the future building market. (in Dutch)

[2] Gassel, van F.,1995, "A method for analyzing mechanized and robotized production processes on the building site", in Automation and Robotics in Construction, ISARC XII, Imbigs, Warszawa.

[3] Vreede, H. de, november 1995, "Development of large equipment too little innovative", Cobouw, The Hague. (in Dutch) 